Ткач Анна Андріївна

старший викладач, Київський наиіональний університет культури і мистеитв Київ, Украӥна anna.arnasio@gmail.com

\title{
ЖІНОЧА СКЛАДОВА В УКРАЇНСЬКІЙ РОДИННІЙ ОБРЯДОВОСТІ
}

Мета роботи. У статті автор досліджує жіночу складову та іiі виокремлення в окремих видах в українській родинній обрядовості, а також регіональні відмінності весільних обрядів. Методологія дослідження полягає в застосуванні системного підходу, який є комплексним і завдяки його використанню можемо більш детально зобразити українську родинну обрядовість у вигляді системи та окреслити жіночу складову в такій системі 3 метою виокремлення жіночої складової в українській родинній обрядовості. Наукова новизна роботи полягає в побудові системного підходу до побудови української родинної обрядовості, надано графічне уявлення про жіночу складову в системі української родинної обрядовості. Автором узагальнено весільні обряди, правила взяття шлюбу, які мали суттєві регіональні відмінності. Висновки. Доведено, що жіноча складова в системі української родинної обрядовості має прояв через вирішальне місце жінки в множині 
складових, видів та форм обрядів, які виступають об'єктом у такій системі. Таке виокремлення $\epsilon$ авторським баченням i жіноча складова в окремих видах української родинної обрядовості наведена в таблицях.

Ключові слова: жіноча складова, українська родинна обрядовість, обряди, весільна, родильна, поховальна.

Ткач Анна Андреевна, стариий преподаватель, Киевский национальный университет культуры и искусств, Киев, Украина

Женская составляющая в украинской семейной обрядности

Цель работы. В статье автор исследует женскую составляющую и ее выделение в отдельных видах в украинской семейной обрядности, а также региональные различия свадебных обрядов. Методология исследования заключается в применении системного подхода, который является комплексным и благодаря его использованию можно более наглядно изобразить украинскую семейную обрядность в виде системы и очертить женскую составляющую в такой системе с целью выделения женской составляющей в украинской семейной обрядности. Научная новизна работы заключается в построении системного подхода к построению украинской семейной обрядности, дано графическое представление о женскую составляющую в системе украинской семейной обрядности. Автором обобщены свадебные обряды, правила взятия брака которые имели существенные региональные различия. Выводы. Доказано, что женская составляющая в системе 
украинской семейной обрядности имеет проявление через решающее место женщины в множестве составляющих, видов и форм обрядов, которые выступают объектом в такой системе. Такое выделение является авторским видением и женская составляющая в отдельных видах украинской семейной обрядности приведена в таблицах.

Ключевые слова: женская составляющая, украинская семейная обрядность, обряды, свадебная, родильная, похоронная.

Tkach Anna, senior lecturer, Kyiv National University of Culture and Arts, Kyiv, Ukraine

\section{The female component in Ukrainian family ritualism}

The purpose of the article is to study the female component and its allocation in Ukrainian family ritualism, along with the regional distinctive features of wedding ceremonies. The research methodology consisted in applying the systematic approach, which is integrated and allows for clearer depiction of Ukrainian family ritualism in the form of a system, and outlining the female component in such system, with the aim of highlighting the female component in Ukrainian family ritualism. The scientific novelty of the work lies in developing a systematic approach to imaging Ukrainian family ritualism, and the introduction of a graphic illustration of the female component in the system of Ukrainian family ritualism. The author generalizes wedding ceremonies and rules, which have significant regional differences. Conclusions. It was proved that the female component in the system of Ukrainian family ritualism manifests through the dominating role of a women in a number 
of components, types and forms of rituals that serve as the subject of this system. Such allocation is the author's vision and the female component in particular types of Ukrainian family ritualism is given in tabular form.

Key words: female component, Ukrainian family ritualism, ceremonies, wedding, maternity, funeral.

Всуп. У всі часи українська родинна обрядовість супроводжувалась вирішальним значенням жіночої постаті. Проте, жіноча особистість приймалась на кожному окремому історичному етапі по-різному - змінювалась загальна концепція сприйняття жінки в суспільстві.

На нашу думку, для виокремлення жіночої складової в українській родинній обрядовості, доцільно використовувати системний підхід. Таке рішення грунтується на наступному:

- по-перше, системний підхід $є$ найбільш комплексним i завдяки його використанню можна більш детально зобразити українську родинну обрядовість у вигляді системи та окреслити жіночу складову в такій системі;

- по-друге, науково-практичне завдання передбачає виокремлення саме жіночої складової, а це безперечно найбільш доцільно визначати саме в системі, бо складова в даному випадку буде найбільш грунтовно виокремлена.

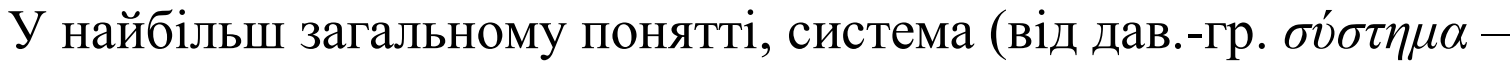
«сполучення», «ціле», «з’єднання») - множина взаємопов’язаних елементів, що утворюють єдине ціле, взаємодіють між собою та середовищем. 
При цьому, в ролі елементів системи доречно визначити іiі суб'єктів, об'єктів, форми, види, складові, мету, завдання та зовнішне забезпечення.

3 урахуванням зазначеного в межах даного дослідження зроблено спробу побудувати систему української родинної обрядовості. Для цього, насамперед, треба визначитись 3 іiі елементами. Так, в ролі суб'єктів доцільно зазначити людину, бо саме кожен окремий індивід виступає суб'єктом української родинної обрядовості. У даному випадку поділимо суб'єктів на три категорії: жінка, чоловік, дитина. Необхідність такого поділу зумовлена розмежуванням ролі жінок, чоловіків та дітей при виконанні окремих обрядів. Поряд із цим, у межах даного дослідження, вивчається саме родинна обрядовість, а жінка, чоловік та діти є структурними компонентами традиційної родини.

Дискусійним є питання виокремлення об'єктів української родинної обрядовості. Так, у загальному, об'єктом у системі виступає то, на що спрямована дія суб'єктів. У цьому сенсі під об'єктами української родинної обрядовості треба розуміти саме обряди як підгрунтя обрядовості.

Стосовно складових української родинної обрядовості, то в даному випадку доцільним є прийняття в якості складових саме сучасних напрямів обрядовості: весільної, родильна та поховальної. У ролі видів можна виокремити соціальну, церковну та внутрішню обрядовість. Такий висновок, на нашу думку, грунтується на тому, що види обрядовості повинні відображати зв'язки родини. Так, соціальна українська родинна обрядовість відображає зовнішні 
зв'язки родини, церковна - релігійні зв'язки родини, внутрішні внутрішні зв'язки між членами родини.

Таке виокремлення видів $є$ безперечно виключним, бо охоплює всі можливі зв'язки родини і в повній мірі відрізняються один від одного, та мають певні особливості. Форми української родинної обрядовості, на наш погляд, повинні бути ототожнені 3 формами обрядів і можуть бути окреслені як традиційні (історично складені) та сучасні.

Завдання та суміжні 3 ними функції має кожний окремий суб’єкт української родинної обрядовості в залежності від кожного окремого обряду.

Зовнішнім забезпеченням української родинної обрядовості виступають духовні, економічні, моральні, соціальні та політичні умови.

У результаті побудови системного підходу до побудови української родинної обрядовості можна надати графічне уявлення про жіночу складову в системі української родинної обрядовості (Рис. 1.).

Як зображено на рис. 1., жіноча складова в системі української родинної обрядовості, насамперед, проявляється в тому, що жінка виступає суб'єктом такої системи. За допомогою певних завдань і функцій, жінка спричиняє вплив на об'єкт системи - обряди, в розмаїтті їх форм, видів і складових. Такий вплив спричиняється задля досягнення загальної мети функціонування окресленої системи. Водночас функціонування системи відбувається завдяки зовнішньому забезпеченню, яке розподілено в залежності від умов 
впливу.

Доцільно більш конкретно розглянути окремі елементи системи 3 погляду окреслення в такій системі саме жіночої складової. При цьому, варто мати на увазі, що мета та забезпечення системи української народної обрядовості $є$ незмінними в залежності від впливу окремих суб'єктів функціонування такої системи. Жіноча складова має прояв лише в межах об'єкту системи української родинної обрядовості, а тому іiї доцільно розглядати в контексті складових, форм та видів обрядів, які виступають відповідно складовими, формами та видами української родинної обрядовості.

Як зазначалось, складовими української родинної обрядовості виступають весільні, пологові та поховальні обряди.

Для усвідомлення жіночої складової потрібно простежити іï зміну протягом останнього часу та витоки ставлення до жінок у весільній обрядовості, які сформували їі сучасний стан. 


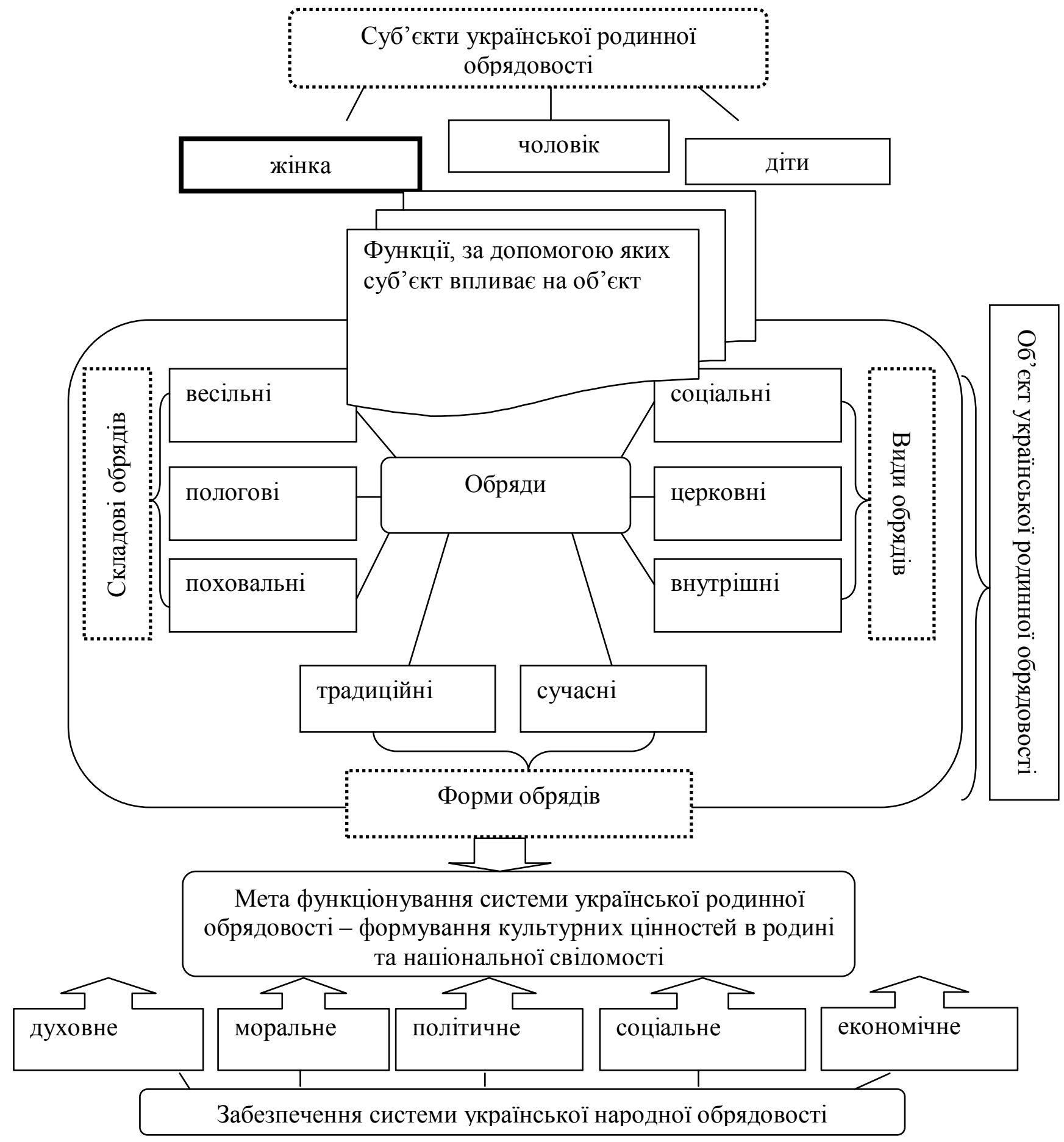

Рисунок 1. Жіноча складова в системі української родинної 
обрядовості (розроблено автором)

Весільна обрядовість - важливий елемент народної культури. Особливості української весільної обрядовості відображено в наукових дослідженнях М. Сумцова [10], М. Костомарова [7], О. Потебні [9], Ф. Вовка [2], М. Грушевського [5].

Аналізуючи українську творчість у психолого-аналітичному контексті, О. Потебня довів тісний зв'язок ідей подружжя і військової відваги. Він зазначав, що в різних слов'янських племен слово «храбр» (хоробрий, воїн) означає не лише героя, а й нареченого. У такому контексті вчений вважав за доцільне тлумачити назву «козак», яка у вітчизняній пісенній традиції водночас вказує на вояка й аманта, героя еротичної лірики. Потебня навів різні мотиви, де завоювання дівчини і шлюб з нею показано в формі завоювання міста, перемоги над ним i, навпаки, завоювання міста, стола, володіння описано в формі сватання [9]. Про подібність мотивів сватання і завоювання згадував М. Костомаров $[7]$.

За М. Грушевським, в ідеї подружжя надовго збережено мотив насильного заволодіння, коли чоловік силою здобуває жінку, що відображено у весільному ритуалі багатьох народів [5].

Весільна обрядовість складалася з багатьох різних обрядів, необхідних для надання шлюбу юридичної сили. В українському середовищі шлюб вважався не особистою справою, тому на нього мали великий вплив як родичі, так i оточення (друзі, дівоча i парубоцька громада, сусіди тощо). В основі шлюбу в Україні в XVI-XIX ст. були «змовини», «згода»- певна угода, яка 
укладалася між батьками та родичами молодого i молодої за посередництвом сватів. Починаючи 3 XVII ст. шлюбна угода оформлялася письмово (спеціальними документами - шлюбними або виновними листами), особливо коли молодим давали (дарували) земельний наділ. Церковне освячення шлюбу входило в побут поступово, починаючи 3 XVI-XVII ст. аж до XIX ст., але скрізь поєднувалося з традиційними звичаями й обрядами.

Починалося все зі сватання, коли запрошені женихом старости (свати) з близьких родичів, взявши обрядовий хліб, йшли до батьків нареченої для отримання попередньої згоди на шлюб. Часто це відбувалося пізно ввечері для збереження таємниці. Відбувався традиційний діалог (із згадкою мисливця і куниці, купця і товару, біблійних персонажів). Якщо згода була отримана, наречена пов’язувала сватам рушники через плече, а нареченому подавала на тарілці хустку, нерідко виготовлену нею, потім запрошувала за стіл. У разі відмови дівчина повертала старостам принесений хліб, а жениху могла подати гарбуза.

Після успішного сватання відбувалися «оглядини» нареченої, а також достатку будинку й господарства молодого (іноді, щоб продемонструвати багатство, батьки жениха йшли на хитрість брали в сусідів коня, мішки 3 зерном та ін.). Потім наставали «заручини» - скріплення договору про шлюб, після якого відмова вважалася недопустимою і спричиняла, крім громадського осуду, ще й відчутний грошовий штраф.

Далі починався період підготовки до весілля, яке звичайно грали восени 3 Покрови (1 жовтня) до Пилипівського посту (14 
листопада) або взимку 3 Хрещення (19 січня) до Масниці. Передвесільні дії починалися з відправлення молодого й молодої на «запросини». Запрошували звичайно всіх родичів, сусідів. Наречена 3 дружкою заходили в будинок i промовляли тричі: «Просили мамо і тато на хліб-сіль, і я прошу на весілля», клали на стіл обрядовий хлібець - «шишку».

Обов'язковою обрядовою дією було прощання жениха i нареченої зі своєю свободою, акт їх відокремлення від несімейної групи молоді. Особливою ліричністю відзначався «дівич-вечір» напередодні весілля, який символізував перехід дівчини в новий статус. Подруги плели вінки і виготовляли «весільне гільце»обліплювали тістом гілку сосни, вишні, черешні, випікали і прикрашали калиною, кольоровими стрічками. Уже в кінці весілля молода відламувала гілочки від «гільця» і роздавала дружкам. На вечорі в жениха виготовляли інший атрибут- весільну шаблю, також яскраво прикрашену. На весіллі ці предмети символічно об’єднувалися. Завершувався вечір «посадом» окремо в хатах жениха і нареченої, коли батьки благословляли молодих.

Церковне вінчання проводили іноді в один день 3 весіллям, іноді заздалегідь, але воно не було головною дією шлюбу. Якщо весілля чомусь відкладалося, звичай не дозволяв вінчаним жити разом. На вінчання молоді вирушали нарізно, отримавши батьківське благословення. Цікаво, що християнський обряд все одно набував у народі магічного характеру. Наречена могла класти за пазуху мак - від корости, а в кишеню- металевий предмет (ключ, ножиці, ніж) від зурочення. У шви одягу з цією ж метою 
встромляли голки, шпильки, у взуття могли покласти ягоди горобини, а на шию повісити прикраси з бурштину. Після вінчання молодих зустрічали біля будинку нареченої. Вони тричі кланялися ii батькам, а ті підносили їм хліб-сіль. У цей же час звичайно відвозили посаг в будинок жениха (скриня, в якій дівчина 3 дитячих років збирала одяг, рушники, прикраси, і куди ніхто не мав права заглядати). У всьому весільному пересуванні молодих супроводжував «весільний поїзд»- супровід 3 бояр жениха i дружок нареченої. На шляху жениха декілька разів організовували «перейми», вимагаючи викуп за наречену. У самому весільному дійстві велику роль відігравали хрещені батьки. Протягом усього весілля здійснювалися такі обряди, які уособлювали ідею родючості й достатку: обсипання молодих зерном i дрібними грошима, переступання через кожух. Почесним гостем вважався чаклун, якого кликали, щоб захистити молодих від причини. Він розкидав по хаті шматочки підсоленого хліба, плюнувши тричі на схід, оглядав кутки, насипав у них жито, траву й золу (проти причини і на здоров’я молодих).

Обов’язковим було гучне гуляння, в процесі якого відбувався обряд дарування, поділ весільного короваю тощо. Найдраматичнішим моментом було розплітання коси i покриття голови молодої очіпком. Це символізувало перехід дівчини в заміжній стан. Відтепер вона не мала права ходити 3 непокритою головою, це сприймалося як великий гріх. За старовинними народними уявленнями, простоволоса заміжня жінка могла накликати хвороби і неврожай. Наречену відвозили в хату жениха, 
де здійснювалося обрядове 3'єднання - молодим перев'язували руки рушником або поясом. Існувало багато символів з’єднання дві паляниці, «весільне гільце» і шабля, дві перев’язані ложки.

Весілля закінчувалося обрядом шлюбної ночі, який включав перевдягання молодої, виведення iї до гостей, демонстрацію цнотливості. Ритуальне приєднання невістки до рідні чоловіка символізували розпалювання нею печі, приготування обіду, пригощання свекрухи. Другий день весілля знаменувався також рядженням - складними театралізованими діями, в яких злилися ігрові розважальні моменти і магічні дійства. Всі перевдягалися, зображаючи тварин, циган, убогих тощо 3 піснями й танцями вирушали до батьків молодої на млинці.

Існував цікавий звичай зображати «фальшиву наречену». Гостей зустрічав дружок, одягнутий в лахміття, 3 кропив'яним вінком на голові, вимазаний сажею, і доводив матері нареченої, що він і є її донькою, аж поки не з'являлася справжня молода.

Весілля завершувалося порідненням двох сімей «дякуванням». Потім ще протягом місяця відбувалися різноманітні взаємні візити, які остаточно оформляли створення нової сім’ї.

Проте весільні обряди, правила взяття шлюбу мали суттєві регіональні відмінності, які узагальнено в (таб. 1).

Таблиия 1.

\section{Регіональні відмінності весільної обрядовості в Украӥні}

(виокремлено автором)

\begin{tabular}{|l|l|l}
\hline Критерій & Регіон & Особливість \\
\hline
\end{tabular}




\begin{tabular}{|c|c|c|}
\hline відмінності & & \\
\hline 1 & 2 & 3 \\
\hline \multirow[t]{5}{*}{$\begin{array}{l}\text { Назва обряду } \\
\text { сватання }\end{array}$} & $\begin{array}{l}\text { у Центральних } \\
\text { районах }\end{array}$ & сватання, рушники \\
\hline & на Закарпатті & Сватанки \\
\hline & $\begin{array}{l}\text { на } \\
\text { Тернопільщині }\end{array}$ & слово, старости \\
\hline & на Поліссі & могорич, змовини, словини, злюбини \\
\hline & на Харківщини & Рушники \\
\hline \multirow[t]{4}{*}{$\begin{array}{l}\text { Обряд } \\
\text { освячування } \\
\text { хлібом }\end{array}$} & На Харківщині & $\begin{array}{l}\text { батько, благословляючи молодят, вручав їм } \\
\text { хліб-сіль напучуючи: «Нате, діти, хліб-сіль, } \\
\text { дбайте і майте, до цього хліба прибавляйте! } \\
\text { Слухайте батька й матері і добрих людей, } \\
\text { одне одного любіть і поважайте» }\end{array}$ \\
\hline & На Рівненщині & $\begin{array}{l}\text { напуття виголошували так: «Візьми, мій } \\
\text { сину, цей хліб і дбай, щоб за цим хлібом ти } \\
\text { свого діждав і мене з матір’ю годував». } \\
\text { Слова, прості й лаконічні, виражали мудру } \\
\text { народну філософію життя - примножувати } \\
\text { хліб і шанувати старших }\end{array}$ \\
\hline & $\begin{array}{l}\text { На Поліссі, } \\
\text { Поділлі, в } \\
\text { Карпатах }\end{array}$ & $\begin{array}{l}\text { молодим підносили окраєць хліба з медом } \\
\text { чи самий лише мед, щоб життя їхнє було } \\
\text { багатим і солодким. }\end{array}$ \\
\hline & на Гуцульщині & $\begin{array}{l}\text { Хлібом батьки благословляють шлюб на } \\
\text { Гуцульщині. Цікаво, що тут у четвер до хати } \\
\text { нареченої приносять сосну і прикрашають їі. } \\
3 \text { нареченою спілкуються п’ять дружок. } \\
\text { Одягає наречену лише та жінка, в якої добре }\end{array}$ \\
\hline
\end{tabular}




\begin{tabular}{|l|l|l|}
\hline & $\begin{array}{l}\text { склався шлюб. Брат розчісує косу нареченої, } \\
\text { а мати накладає шлюбний вінок. Молода } \\
\text { просить пробачення у батьків і отримує їхнє } \\
\text { благословення }\end{array}$ \\
\hline $\begin{array}{l}\text { Обряд } \\
\text { використання } \\
\text { рушника }\end{array}$ & Київщина & $\begin{array}{l}\text { Молода могла взяти рушник або } \\
\text { відмовитися, своїм вчинком вона давала } \\
\text { згоду на весілля або навпаки }\end{array}$ \\
\hline
\end{tabular}

Другою складовою української родинної обрядовості $\epsilon$ пологова (родильна) обрядовість, місце жіночої складової, в якій, безперечно, є вирішальним і першочерговим.

У родинній обрядовості виділяють допологові обряди, пологи, післяпологові обряди.

Щоб дитина стала розумною та вченою, пуповину відрізали на книзі; при першій купелі немовляті вкладали у руки, крім інших предметів, книгу. За книгою ворожили на долю дитини; після хрещення відкривали книгу 3 духовними піснями, намагаючись відгадати за їх змістом майбутнє. Щоб визначити здібності дитини, на першу річницю або в день відлучення від грудей перед нею клали книгу, хліб, монету інші предмети і дивилися, що вона зразу візьме. Магічною силою наділяли також вузол. У випадку, коли пологи були тяжкими, в хаті відчиняли усе, що відчиняється: двері, вікна; відмикали скрині, розв'язували вузли, щоб так само розв’язався вихід дитини. Коли дитина народжувалася, то бабаповитуха відтинала їй пупчик, зав’язувала його «у сім гудзів» i передавала матері. Коли ж дитині виповнювалося сім років, мати давала їй того ремінчика, щоби «руками позад себе розв’язала. 
Якщо розв'яже, то їй розум розв'яжеться, до голови впуститься». Зав'язаний вузол сприймався як символ перешкоди, невдачі; розв’язаний вузол означав волю, спасіння [3].

Основними символами родильної обрядовості українців вважаються вода, вогонь, хліб, зерно, глина 3 печі; предмети рослинного світу; їжа, питво, вироби з металу, знаряддя праці, компоненти одягу. Допологові звичаї та обряди становили систему раціональних знань і магічних дій, що виконувались із метою запобігти бездітності, й при народженні дитини; різні прикмети, за якими прагнули передбачити вагітність і стать майбутньої дитини; повір'я, покликані охороняти здоров'я породіллі та немовляти тощо. Дії, які виконувала баба-повитуха, засвідчували аграрні засади родильної обрядовості (зав'язування та відрізання пупка, перша купіль, перше годування, відвідування породіллі). Пуповину повсюдно зав'язували лляним чи конопляним прядивом, а в 20х pp. XX ст. використовували рубчик або магазинну нитку. Післяпологові обряди поділялися на дві групи: одні - для очищення і захисту породіллі та немовляти від впливу злих сил і духів, від вроків; інші - для того, щоб уберегти близьких породіллі людей і навколишній іiі світ (худобу, криницю, урожай) від негативного впливу «нечистої» після «злогів» жінки [4].

В Україні після народження дитини виконувалися певні обряди: відвідування породіллі, вибір кумів, прилучення дитини до родини, хрещення (через тиждень або два після народження переважно Полісся і східні області; подекуди - i в день народження - Бойківщина, Гуцульщина), пострижини тощо. 
Дослідники описують давній слов'янський обряд магічного «введення» дитини у сімейний колектив. Немовля загортали у вивернутий кожух (символ достатку, здоров'я, сімейної злагоди, щастя) й обносили навколо помешкання, біля хлопчика клали якийсь інструмент, щоб виріс умільцем, біля дівчинки - жмутик льону, символ жіночого заняття [5].

Унаслідок розселення малих сімей і послаблення родинних відносин виник Інститут кумівства. Вперше у Статуті Ярослава Мудрого вжито термін кум, але цей звичай здавна побутував як загальнонародний. Кумівство - наслідок розкладу родової общини, коли в своїй сім’ї дядько вже не виховував племінників, а ставав для них духовним наставником у сім'ях їх батьків. У процесі християнізації Русі народний звичай кумівства використала церква, кум і кума були оголошені хрещеними батьками [6].

Здавна дотримували звичаїв вшановувати матір i новонародженого. Ці звичаї мали назву родини. За звичаєм на «родини» йшли лише жінки, які приносили невеликі дарунки, переважно пиріжки, мед, крупу, полотно [1].

Хрещення (хрестини) символізує прилучення новонародженої дитини до родового культу. За стародавнім звичаєм, немовля брали на руки, клали на землю, на поріг; тоді піднімали й обходили тричі навколо хати. Після купелі баба-повитуха сповивала хлопчика в сорочку батька, розрізуючи їі в трьох місцях, а дівчинку - в сорочку матері, зав'язавши в рукав шматочок печини, вуглик, монету; потім передавала дитину куму, а той - кумі. Хлопчика передавали на порозі, дівчинку - через грубінь, після чого йшли до 
церкви хрестити. Поріг символізував межу двох світів: свого і чужого; господарю-батькові доручалося підняти дитину, тобто прийняти іiі (чи ні) у свій рід. Після хрещення справляли хрестини. Тоді батьки вибирали дитині хрещеного батька i матір, які поручалися за іiі виховання у випадку смерті батьків. На хрестини хрещені батьки приносили хліб, бублики і крижмо (декілька аршинів полотна), а хрещена мати - ще й хрещик. На другий день хрестин родичі породіллі влаштовують похрестини - частування на честь кумів і баби-повитухи. Це певний відгомін часів, коли дитину відносили до роду матері, а не батька. Через рік (інколи пізніше) після народження дитини в Чистий четвер здійснювали урочисті перші пострижини - ритуал, який мав уберегти дитину від хвороб. Цього ж дня вистригали шерсть на лобі тварин, підрізали хвости в коней, курей, щоби плодилися. Малюка садовили на розстеленому вовною догори кожусі, а кум відстригав трохи волосся спереду, ззаду та з обох боків біля вух. Після пострижин батько кидав на кожух трохи жита й грошей, «щоб дитина багата й щаслива росла». Хлопчика стригли на сокирі, а дівчинку - на коноплях. Відрізане волосся зберігали до наступної стрижки, а потім кидали в чисту проточну воду [3]. У родильній обрядовості вагоме значення мають рушники. Наприклад, на Підляшші (тепер Польща) в рушник загортали немовля після народження. У надбужанських селах повитуха витирала рушником дитину до хрестин, а породілля дарувала їй рушник з хлібом й іншими продуктами. Куми, йдучи до дитини на хрестини, несли три хлібини, загорнуті в рушник [8].

Третя складова української родинної обрядовості - 
поховальна. Обряди, пов'язані зі смертю людини, включають поховальні і поминальні. Смерть людини сприймалася i як величезне горе, і як необхідність. Неоднозначне ставлення до смерті обумовило формування складної системи поховальних обрядів, основою яких був культ предків. Всі дії, які супроводили поховання небіжчика, були спрямовані на забезпечення переходу душі покійного на «той світ» і охорону живих від шкідливого впливу духу вмерлого, адже вважалося, що дух за певних умов може повернутися. Після похоронів влаштовували поминки.

Біля вмираючого рідні старалися бути невідлучно, щоб полегшити йому відхід 3 життя. Для цього відчиняли двері, вікна, робили в стіні хати отвори. Після настання смерті завішували дзеркала і виливали всю воду, яка була в будинку. Небіжчика обмивали, а предмети, що використовувалися для цього, ретельно закопували в землю- щоб не нашкодили живим. Потім вмерлих обряджали, звичайно в новий одяг, взували рідко. При похованні неодружених дівчат або юнаків використовували деякі елементи весільної обрядовості. Так, дівчину одягали у весільний одяг, на руку ліпили перстень 3 воску, пов'язували весільний рушник, розплітали коси. Юнаку прив'язували до пояса червону хустку. Існував звичай вибирати небіжчику пару з числа живих. Вибрані «князь» або «княгиня» грали роль жениха або нареченої, а потім безутішних вдівців.

Ховали, звичайно, через три дні після смерті, і в похоронах брало участь, зазвичай, все село. Тут також дотримувалися таких ритуалів. Труну виносили «ногами уперед», іноді спеціально тричі 
зачіпаючи за поріг. Ворота могли пов’язати рушником або червоним поясом, а в хліві розсипали овес, щоб худоба не пішла за господарем. Після винесення хату вимітали, підлогу мили або посипали зерном. Відкриту труну звичайно несли на руках або везли на возі, потім, забивши, опускали на рушниках в могилу.

Кожний присутній повинен був кинути жменю землі. В Україні було прийнято «печатати могилу»- сипати першу землю на труну хрестоподібно. Обов'язковою була поминальна трапеза 3 вживанням ритуальних страв, зокрема куті. За столом на покуті покійному залишали місце, кладучи для нього хліб і ложку. Такі ж поминки влаштовувалися через день, дев’ять і сорок днів, потім через рік. 3 сороковим днем було пов'язане традиційне уявлення про остаточний відліт душі. Надалі поминальні обряди поєднувалися з релігійними святами.

Отже, попередні дослідження дозволили нам зробити висновок про наявність трьох видів родинної обрядовості церковної, соціальної та внутрішньої. Таке виокремлення $\epsilon$ авторським баченням. Жіноча складова в окремих видах української родинної обрядовості наведена в (таб. 2.).

Таблиия 2.

Жіноча складова в окремих видах української родинної обрядовості

(виокремлено автором)

\begin{tabular}{|c|c|c|}
\hline Вид & $\begin{array}{c}\text { Характеристика } \\
\text { виду }\end{array}$ & Жіноча складова \\
\hline
\end{tabular}




\begin{tabular}{|c|c|c|}
\hline 1 & 2 & 3 \\
\hline Церковна & $\begin{array}{l}\text { С системою } \\
\text { відносин між } \\
\text { окремою людиною } \\
\text { та церквою, що } \\
\text { передбачає } \\
\text { виконання певних } \\
\text { церковних обрядів }\end{array}$ & $\begin{array}{l}\text { Місце жінки в церковній обрядовості завжди } \\
\text { було другорядним: жінкам заборонялося } \\
\text { входити до вівтаря, заборонялося } \\
\text { прикладатися до певних ікон, які в ньому } \\
\text { знаходяться, заборонялося навчання в } \\
\text { духовних семінаріях тощо. Це пов’язано, } \\
\text { насамперед, із зрадою Сви, яка вважається } \\
\text { праматір’ю всіх жінок. Водночас жінки } \\
\text { активно заохочуються до церкви в ролі } \\
\text { парафіян, передбачається участь жінок в } \\
\text { освячуванні кулічів, води, верби, участь у } \\
\text { хрестильних обрядах. Тобто, жіночу складову } \\
\text { в церковній обрядовості можна визначити як } \\
\text { заохочувально-обмежувальну }\end{array}$ \\
\hline Соціальна & $\begin{array}{l}\text { Є системою } \\
\text { взаємозв’язку } \\
\text { членів певної } \\
\text { родини із } \\
\text { зовнішнім } \\
\text { оточенням }\end{array}$ & $\begin{array}{l}\text { Сьогодні в Україні зв’язок жінок та чоловіків } \\
\text { iз зовнішнім світом, суспільством можна } \\
\text { вважати в повній мірі рівноправним. Жіноча } \\
\text { складова в жодному разі не обмежується в } \\
\text { правах та можливостях спілкування }\end{array}$ \\
\hline Внутрішня & $\begin{array}{l}\text { Є системою } \\
\text { взаємовідносин в } \\
\text { родині }\end{array}$ & $\begin{array}{l}\text { Жіноча складова в цьому випадку цілком } \\
\text { залежить від устрою самої родини та } \\
\text { визначається кожною родиною окремо, але } \\
\text { існують традиційні погляди на місце жінки в } \\
\text { родині, які передбачають їі головний } \\
\text { обов’язок виховання дітей, приготування їжі } \\
\text { та прибирання в оселі. }\end{array}$ \\
\hline
\end{tabular}

Таким чином, жіноча складова в системі української родинної 
обрядовості має прояв через вирішальне місце жінки в множині складових, видів та форм обрядів, які виступають об'єктом у такій системі і є актуальними для подальшого дослідження.

\section{Список використаних джерел}

1. Борисенко В.К. Весільні звичаї та обряди на Україні / В. К. Борисенко. - Київ : Наук. думка, 1988. - 192 с.

2. Вовк Ф. Незабытое наследие [Электронный ресурс] / Ф. Вовк. - Режим доступа : http://pandia.ru/text/77/153/15768.php. Загл. с экрана.

3. Войтович В. Українська міфологія / В. Войтович. - Вид. 2ге. - Київ : Либідь, 2005. - 664 с.

4. Гвоздевич С. Родильна обрядовість українців / С. Гвоздевич // Народознавчі зошити. - 1997. - № 2 (14). - С. 111-122.

5. Грушевський М. С. Нарис історії українського народу/ М. С. Грушевський. - Київ : Либідь, 1991. - 398 с.

6. Косвен М. О. Семейная община и патронимия М. О. Косвен. - Москва, Изд-во АНСССР, 1963. - 219 с.

7. Костомаров M. I. Слов'янська міфологія М. І. Костомаров. - Київ : Либідь, 1994. - 384 с.

8. Никорак О. I. Народні шкіряні вироби українців. Витоки, становлення і розвиток традицій / О. І. Никорак.- Львів : Ін-т народознавства НАН України, 2016. - С. 17-23.

9. Потебня А. А. О мифическом значении некоторых обрядов и поверий / А. А. Потебня. - Москва : В Университетской типографии, $1865 .-310$ с. 
10. Сумцов Н. Ф. Символика славянских обрядов : избранные труды / Н. Ф. Сумцов. - Москва : Восточная литература PAH, 1996. - 296 c.

\section{References}

1. Borysenko, V. (1988). Wedding customs and traditions in Ukraine. Kyiv: Naukova Dumka.

2. Vovk, F. (2012). Unforgettable heritage. Available at: <http://pandia.ru/text/77/153/15768.php> [Accessed 17 November 2016].

3. Voitovych, V. (2005). Ukrainian mythology. Kyiv: Lybid.

4. Hvozdevych, S. (1997). Maternal ritual of Ukrainians. Narodoznavchi zoshyty [Cognitive notebooks], no. 2 (14), pp. 111-122.

5. Hrushevskyi, M. (1991). Essay on the history of the Ukrainian people. Kyiv: Lybid. p. 398.

6. Kosven, M. (1991). Family community and patronymy. Moscow: Izdatel'stvo Akademii nauk SSSR.

7. Kostomarov, M. (1994). Slavic mythology. Kyiv: Lybid.

8. Nykorak, O. (2016). National leather goods in Ukraine. The origins, formation and development of traditions . Lviv: Institute of Ethnology of NAS of Ukraine. pp. 17-23.

9. Potebnia, O. (1865). On the mythical meaning of certain rituals and beliefs. Lviv: The University press.

10. Sumtsov, N. (1996). The symbolism of Slavic rites. Moscow: Publishing company «Eastern literature» Russian Academy of Sciences.

(C) Ткач A. A., 2017 